\title{
NOTES ON MYXOMYGETES I \\ SOME REMARKS ON THE GENUS RETICULARIA \\ BULL. EMEND. ROST.
}

\author{
N. E. NANNENGA-BREMEKAMP \\ (Doorwerth)
}

(received September 22nd, 1958)

The genus Reticularia was established in 1789 by BULLIARD, and comprised originally twelve species. Some of these were afterwards removed to Fuligo, Mucilago, Diderma and Physarum. Rostafinskr (1873 and 1875) gave the genus a new circumscription, and retained but a single species, viz. Reticularia lycoperdon. The chief characters of the latter are: fructification an aethalium composed of numerous interwoven sporangia; sporangial walls partly evanescent, the persistent part consisting of broad membranes and strands fraying out into delicate capillitium-like threads.

In 1876 Rostafinski (Mon., App.: 33) tentatively referred a second species to the genus, viz. R.? rozeana, which can not be recognized with certainty from the description. At two different occasions, however, attempts have been made to identify it with material collected at a later date, viz. first by Lister and afterwards by Wingate.

In 1891 LISTER published in the Journal of Botany a description of a Myxomycete which he thought to be identical with the species of Rostafinski, but which he afterwards recognized as distinct; it has been entered under the name $R$. lobata in the first edition of his monograph (1894). Because of the distinct, though closely aggregate fruiting bodies with fragile membranous walls TorRend (Bull. Soc. Port. Sc. Nat. 2: 63. 1908) created for this species a new genus, which he called Liceopsis.

Morgan described and figured in 1893, in the Journal of the Cincinnati Society of Natural History, under the name $R$. splendens a new species to which we will return below, and in 1895 in the same journal a $R$. nitens. According to the second edition of Lister's "Monograph" the latter is to be identified either with Stemonitis confluens or else with the habitually similar Amaurochaete cribrisa. At any rate, as it can not belong to Reticularia it may be left out of consideration.

In 1908 MeyLan described in the Bulletin de la Société Vaudoise des Sciences Naturelles a new species, $R$. jurana, which was based on material collected in the Jura Mountains. G. Lister was of opinion that this could at the most be regarded as a somewhat dubious variety of $R$. lycoperdon, and other authors (e.g. Macbride and Martin and Hagelstein) merely cite Meylan's name as a synonym of the latter, probably following G. Lister's suggestion. However, I have repeatedly collected specimens whose characters fully agree with Meylan's description, which in fact is an excellent one, and I find 
that the differences are well-marked and fully constant. For this reason Meylan's species is here reinstated in its original status.

Torrend's genus Liceopsis has been accepted by several authors, although they all agree that it is to be regarded as closely related to Reticularia. At the same time, however, it was recognized that $L$. lobata shows a close resemblance to a species which Wingate had referred to the genus Enteridium, and which the latter had called $E$. rozeanum, because he regarded it as conspecific with Reticularia? rozeana Rost. As I will show further on, this identification can not be accepted. As it appears to be conspecific with $R$. splendens Morg., the correct name of Wingate's species under Enteridium is $E$. splendens (Morg.) Macbride.

In 1948 MARTIN returned Liceopsis lobata to the genus Reticularia, because he recognized that the fructifications were no sporangia, but minute aethalia. So, in fact, they had already been described by Lister.

In studying these species I was struck with the peculiar character of their spores, which, it is true, had already drawn the attention of Massee (Mon. of the Myxogastres, 1892), who described and figured it in Reticularia lycoperdon and in Enteridium rozeanum. The peculiarity of these spores is that they are covered for about two thirds of their surface by a reticulate wall, whereas the remaining part, the area of dehiscence, has a much thinner wall, which may be either smooth, faintly warted or brokenly reticulate.

The similarity in spore structure induced me to look for other points of resemblance between Reticularia lycoperdon, $R$. jurana, Liceopsis lobata, Enteridium splendens, and the new species which I will describe below under the name Reticularia intermedia. It then appeared that the pseudo-capillitium, i.e. the remnants of the walls of the individual sporangia, shows in these species structures that may be regarded as modifications of one and the same type. In Reticularia lycoperdon (Fig. 1, c) it consists of membranous plates fraying out into strands and threads, in $R$. intermedia (Fig. 2, b) it is almost entirely reduced to a mass of fine threads, in $R$. jurana (Fig. $3, \mathrm{c}$ ) the threads are combined into a wide-meshed network, and they may occasionally (Fig. 3, f) reach a considerable width; in the first case they resemble the scanty threads to which the pseudo-capillitium of Liceopsis lobata (Fig. 4, I b) is reduced, and in the second that of Enteridium splendens (Fig. 4, II b), which consists of perforated plates. The close resemblance between the pseudo-capillitium of Liceopsis lobata and of Enteridium splendens with that of Reticularia jurana convinced me that these two species should be returned to the genus Reticularia. It is noteworthy that in the other Enteridium species the spore wall is minutely warted.

In order that Liceopsis lobata and Enteridium splendens may be returned to Reticularia, the generic diagnosis should be emended as follows:

Fructification an aethalium; pseudo-capillitium sometimes consisting of membranes that are either frayed into strands and threads or provided with several large rounded perforations, and sometimes of strands and threads which eventually may be combined into a 
network. Spores brown in mass, with a thickened reticulate wall covering about two thirds of the surface; the area of dehiscence much thinner and either brokenly reticulate, faintly warted or smooth.

\section{KEY TO THE SPECIES AND VARIETIES}

1a. Pseudo-capillitium dendroid. Aethalium $0.5-8 \mathrm{~cm}$ in diam.

2a. Pseudo-capillitium consisting of flat membranes which branch in a dendroid fashion and go out in a mass of flexuous threads. Cortex thick, at first silvery white, afterwards covered with spores and then dull. . . 1. R. lycoperdon

a. Spores adhering to the threads in loose clusters. . var. lycoperdon b. Spores free . . . . . . . . . . . . . . var americana

2b. Pseudo-capillitium consisting throughout of fine threads branching in a dendroid fashion. Cortex thin, evanescent 2. $R$. intermedia

1b. Pseudo-capillitium forming a homogeneous network. Aethalia rarely more than $2 \mathrm{~cm}$ in diam., in $R$. splendens, according to Martin, up to $6 \mathrm{~cm}$

3a. Pseudo-capillitium membranous, crisp, with large rounded perforations. Cortex glossy brown . . . . 3. R. splendens

$3 \mathrm{~b}$. Pseudo-capillitium either consisting of soft flaccid membranes with rounded perforations or of a large number of anastomosing strands, or scanty. Cortex thin, evanescent or more or less persistent and then iridescent

4a. Aethalia 2.5-25 $\mathrm{mm}$ in diam., single or up to four together. Cortex transparent, usually evanescent; surface bullate (revealing the outlines of the sporangium tops). Pseudo-capillitium consisting of flaccid membranes with rounded perforations or of a large number of anastomosing strands. Spores with a faintly warted or smooth area of dehiscence. . . . . 4. R. jurana

4b. Aethalia $0.4-1.1 \mathrm{~mm}$ in diam., densely clustered, rarely free. Gortex thin and iridescent. Pseudo-capillitium scanty or, rarely, absent. Spores with a brokenly reticulate or smooth area of dehiscence 5. R. lobata

\section{Description OF THE SPECIES AND VARIETIES}

1. Reticularia lycoperdon Bulliard, Herb. de la France: Table 446, Fig. 4. 1789. var. lycoperdon (cf. Fig. 1)

Aethalia (Fig. 1, a) pulvinate, large, $0.5-8 \mathrm{~cm}$ in diam., usually solitary; hypothallus large, white; cortex thick, silvery white at first afterwards covered with spores and dull; pseudo-capillitium (Fig. 1, $b$ and c) arising in the form of erect crisp plates from the base of the aethalium, branching in dendroid fashion and going out in thin flexuose threads, which are but for a small part connected with the cortex; spores in mass rusty brown when fresh, turning dark fuscous afterwards, adhering to the threads in large clusters (Fig. 1, d); the 


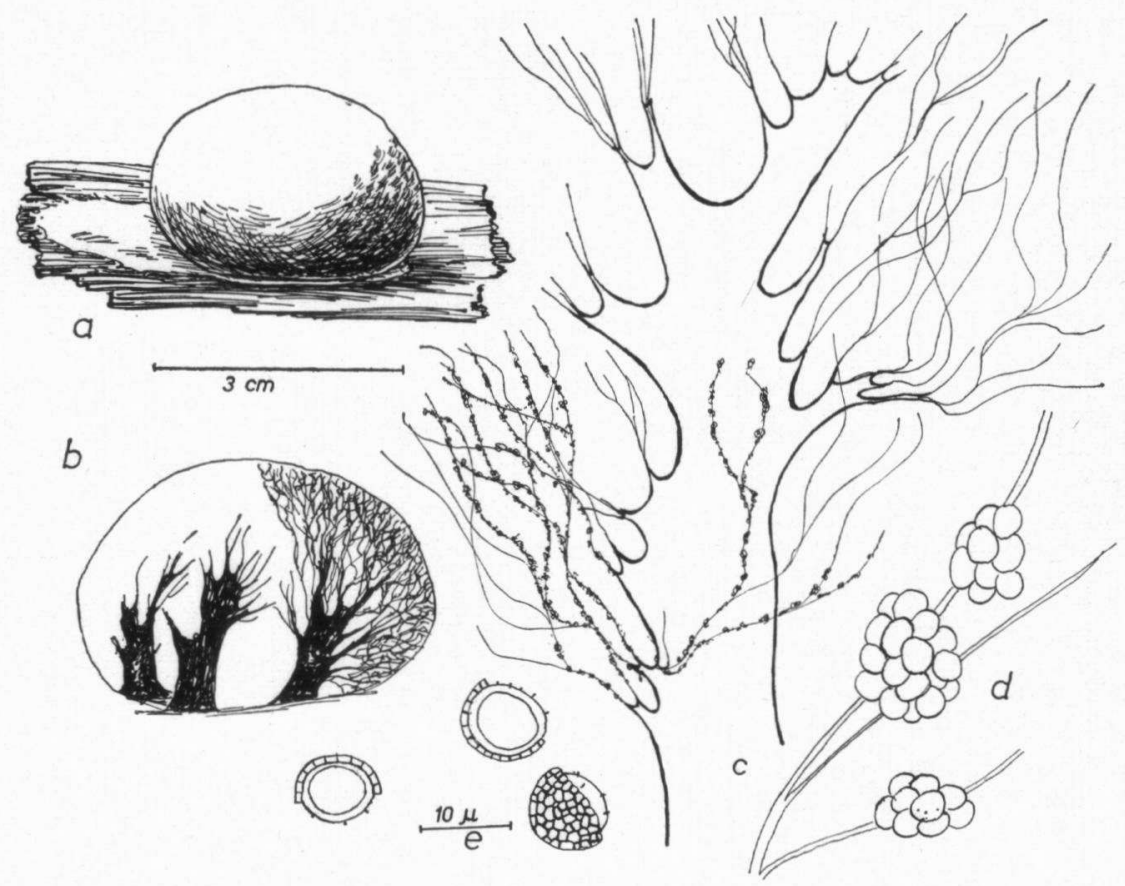

Fig. 1. Reticularia lycoperdon Bull. var. lycoperdon. a. aethalium; b. aethalium halved; c. plate of the pseudo-capillitium branching into threads; $d$. threads with adhering spores; e. spores, one in optical section.

individual spores (Fig. 1, e) subglobose to turbinate, 8-11 $\mu$ in diam.; the thick part of the wall conspicuously reticulate, with about 11 meshes on half a great circle; the area of dehiscence faintly warted. Plasmodium white.

All the specimens from the Netherlands (vicinity of Doorwerth) which I have collected $(210 \mathrm{U}, 231,534,1022,1693,1850,1887$, $1936,2176,2323,2557,2566,2826,2843,2932$ ) as well as the two from England which I have studied in detail (Ashbridge Park, Berks, N. E. NANNENGA-BREMEKAMP 2560; Lister collection 1447 BM) belong to the var. lycoperdon. The spores in this variety adhere always in clusters to the threads of the pseudo-capillitium, and these clusters are sometimes so large as to be visible by a 10 times magnifying lens; the spores cling to the threads very tenaciously, whereas in the other species it is usually possible to blow them more or less completely away from the pseudo-capillitium.

In Martin's monograph of the Myxomycetes in the "North American Flora" $R$. jurana is given as a synonym of $R$. lycoperdon, but as the spores of the latter are described as 8-9 $\mu$ in diam., $R$. jurana has apparently not been included in the description of the species, as its spores are 6-8 $\mu$ in diam.

The spores of $R$. lycoperdon are described by Martin as free, and 
this evidently means that the North-American material studied by him, can not be identical with the specimens on which the European authors have based their descriptions. This view was confirmed by the study of a specimen from the U.S.A., kindly sent me by Prof. Dr. G. W. Martin. The spores of this specimen have a coarser reticulation than the European ones, showing about 7 meshes to half a great circle. The spore figured in "The Myxomycetes" by MACBRIDE and Martin, 1934, Plate XVI, Fig. 403, shows this feature too. In my opinion the American Reticularia lycoperdon represents a distinct variety. ${ }^{*}$ )

Var. americana nov. var.; Reticularia lycoperdon ex G. W. MARTIN, North American Flora I, part 1: 22-23. 1948 (cf. Fig. 2).

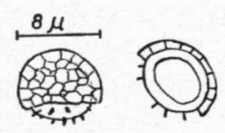

Fig. 2. Reticularia lycoperdon var. americana; spores, one in optical section.

Sporis liberis, reticulo laxiore, a typo recedens. N. E. NAnnengaBremeKamp 3106, typus. Iowa.

As stated above, this variety differs from the var. lycoperdon by the free, more coarsely reticulate, spores.

Macbride and Martin say in their monograph (p. 240) that RostAFINSKI and Lister cite Mucos lycogalum Bolton (Hist. Fung. 3: 153. 1789) as a synonym, and they add that if this is correct, the epithet lycogalum should take precedence over lycoperdon, of which they say that it was published in 1791. However, this is a mistake; the name lycoperdon dates in reality from 1789 , i.e. from the same year as Bolton's name, so that there seems to be no reason to change the epithet.

In how far the synomyns of $R$. lycoperdon quoted by Rostafinski and subsequent authors belong to the var. lycoperdon, the var. americana, $R$. jurana or even to other genera, will be difficult to make out, as the descriptions and figures are not sufficiently detailed, and as no types are available. The best way out of the difficulty is doubtless to discard them as insufficiently known.

2. Reticularia intermedia nov. spec. aethaliis magnis et pseudo-capillitio dentroideo ad $R$. lycoperdon accedens, sed cortice tenui et evanescente necnon pseudo-capillitio toto e filamentis composito ab ea recedens (cf. Fig. 3).

Aethalia (Fig. 3, a) pulvinata, 0.5-2 cm diam., singula, prophyrea

*) A specimen received, after this had gone to the press, from Dr. Martin (3116 of my collection) collected in Iowa, proves that the var. lycoperdon occurs in America too. 


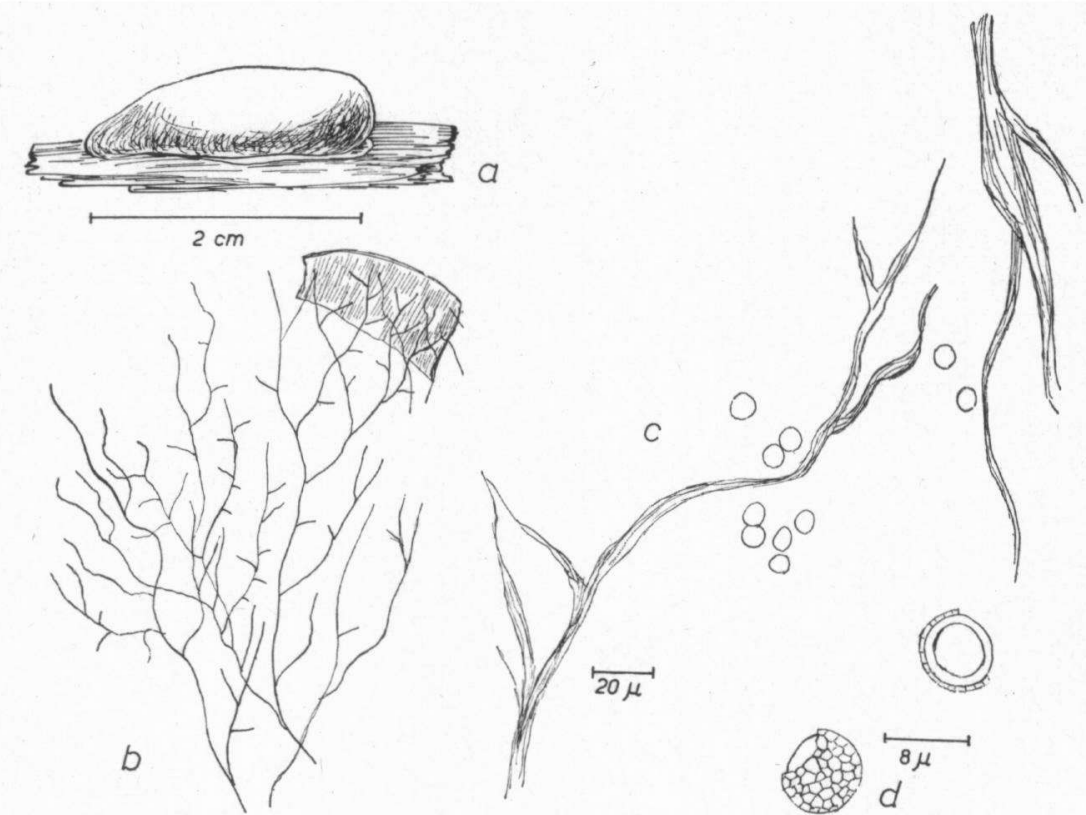

Fig. 3. Reticularia intermedia nov. spec. a. aethalium; b. threads of the pseudocapillitium with part of the cortex; c. threads still further enlarged; d. spores, one in optical section (N-B 727).

vel rufa; hypothallus nunc annuli albi instar sub aethalio praestans, nunc inconspicuus; cortex fragilis, evanescens; pseudo-capillitium (Fig. 3, b et c) profusum, sub forma reticuli dendroidei densi e ligamentis et filamentis compositi per aethalium totum extendens, sporis flatu caute deturbatis collabens; sporae (Fig. 3, d) liberae, per saturam ferrugineae, ad lucem orientem versus visae pallidae, 7-9 $\mu$ diam., tenuiter reticulatae, maculis in dimidia parte lineae sporam ad medium circumcurrentis visis circ. 8 , area dehiscentiae laevi. Plasmodium album.

Habitat locum "Boersberg" prope vicum "Doorwerth" in provincia Gelria, N. E. NANNENGA-BREMEKAMP 727, typus; prope "Doorwerth" ad locos alios, ead. 20 (U), 2118, 2607, 2808, 2913.

Aethalia (Fig. 3, a) pulvinate, $0.5-2 \mathrm{~cm}$ in diam., solitary, red brown or coppery; hypothallus showing as a white rim round the base of the aethalium or inconspicuus; cortex frail, evanescent; pseudo-capillitium (Fig. 3, b and c) profuse, forming a dense dendroid network of thin strands and threads extending throughout the aethalium; when the spores are gently blown away, the pseudo-capillitium collapses; spores (Fig. 3, d) free, rusty brown in mass, pale by transmitted light, 7-9 $\mu$ in diam., delicately reticulate, with about 8 meshes on half a great circle, and a smooth area of dehiscence. Plasmodium white.

The type was collected on the "Boersberg" near Doorwerth in 
the province of Gelderland, the Netherlands; the other specimens cited under the latin description are from the same neighbourhood; no 20 is in the Utrecht herbarium, where the type will be deposited too.

$R$. intermedia resembles $R$. lycoperdon in the way in which the pseudocapillitium is branched, but it has the frail cortex of $R$. jurana, which it resembles also in the delicately reticulate spores.

That $R$. intermedia would be restricted to the neighbourhood of Doorwerth, is hardly conceivable. It seems more probable that it has but rarely been collected or kept, because it is so extremely fragile.

3. Reticularia splendens Morgan in Journ. Cinn. Soc. Nat. Hist. 15: 137. 1893; Enteridium splendens (Morg.) MAcBrIDE, the NorthAmerican Slime-moulds 151. 1899; - E. rozeanum (Rost.) Wingate in Proc. Ac. Nat. Sc. Phila. 1889: 156. 1889 quoad specimen descriptum, haud quoad typum qui est Reticularia? rozeana Rost., Mon., App. 33. 1876, species e descriptione haud certe noscenda; (cf. Fig. 5 II).

Aethalia (Fig. 5-II-a) pulvinate, $0.5-6 \mathrm{~cm}$ in diam., solitary or gregarious, reddish brown or umber; hypothallus white, usually forming a conspicuous ring round the base of the aethalium; cortex tough-cartilageneous, smooth or rough; pseudo-capillitium (Fig. 5-II-b) a uniform network of anastomosing crisp plates with several rounded perforations and extending from the base of the aethalium to the cortex, sometimes with frayed margins or lobes; spores (Fig. 5-II-c) free, brown in mass, pale brownish yellow by transmitted light, 7-9 $\mu$ in diam., distinctly reticulate, with about 8 meshes on half a great circle, and a finely warted area of dehiscence. Plasmodium watery white, changing through rose to brown.

The description given above is based for a large part on that given by Martin, North-American Flora I, part 1: 23. 1948. The few particulars that were added, were obtained by the study of a specimen in the British Museum (1445 BM) and of one in my own collection (2078), which I received from Dr. MARTIN; both specimens were collected in Iowa.

$R$. splendens was based on North-American material, and is not known to me from other regions. It is rather like $R$. jurana in colour and shape, and sometimes in internal structure too, but it is at once distinguishable by the crisp and shiny character of the papery cortex and of the pseudo-capillitium. Cortex and capillitium of $R$. jurana are much softer, more lace-like, and more delicate.

The epithet "rozeana" can not be used for this species, as it can not be regarded as conspecific with $R$.? rozeana Rost. The spores of Rostafinski's species are described as "uniformly spinulose reticulate", and this does not fit those of the species described above. As the type of Rostafinski's species seems to be lost, it is, of course, impossible to decide whether the description of the spores is correct, but in the absence of evidence proving that it is incorrect, it has to be accepted as it stands. This means that Rostafinski's species can not be accepted as identical with that described by 2 Wingate as Enteridium rozeanum. 
For the same reason it can not be conspecific with Reticularia lobata, as Lister originally thought.

4. Reticularia jurana Meylan in Bull. Soc. Vaud. d. Sc. Nat. 44: 277. 1908 (cf. Fig. 4).

Aethalia (Fig. 4a) pulvinate, $2.5-25 \mathrm{~mm}$ in diam., solitary or up to four together, scattered, red brown or coppery; hypothallus visible as a white rim around the base of the aethalium, the whole but lightly

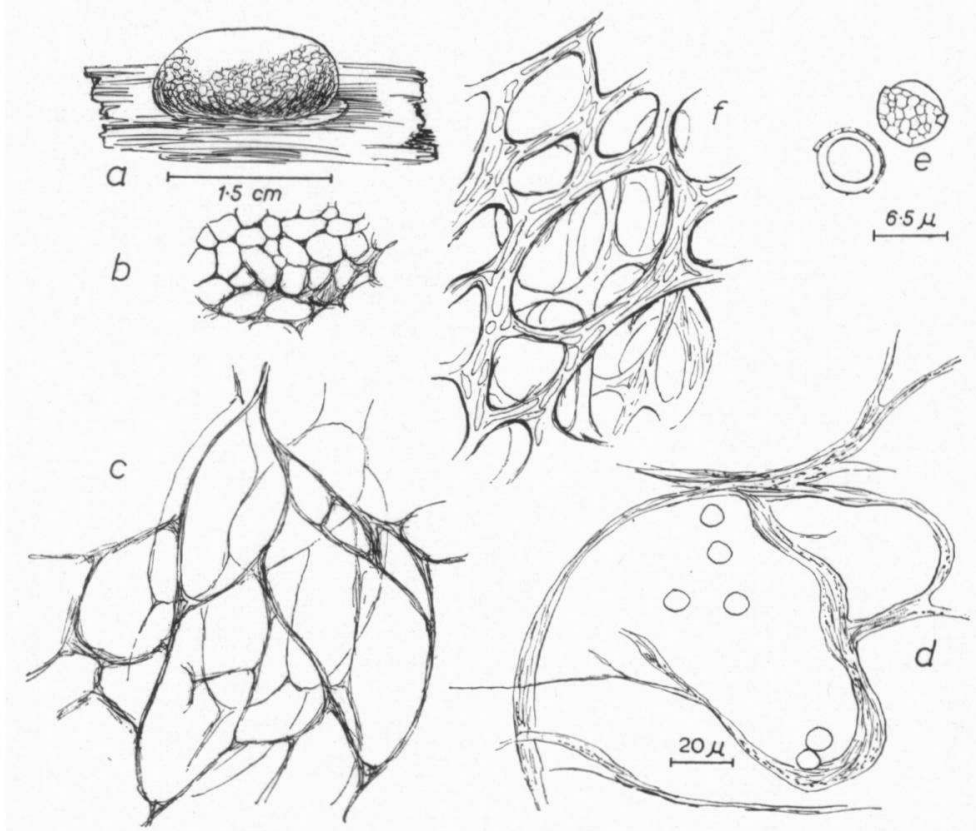

Fig. 4. Reticularia jurana Meylan. a. aethalium; b. surface structure of aethalium; c. pseudo-capillitium; d. the same, still further enlarged; e. spores, one in optical section; f. pseudo-capillitium from another specimen, consisting of peforated membranes.

attached to the substrate; cortex usually very frail and evanescent, although sometimes, especially at the base, somewhat more resistent, thinly membranous, bullate, the convexities (Fig. 4b) indicating the tops of the individual sporangia; pseudo-capillitium (Fig. 4-c, $d$ and $f$ ) forming a uniform network of flaccid membranes and threads extending throughout the aethalium, the membranes sometimes perforated; although very fragile, the pseudo-capillitium yet retains its spongy character if the spores are blown away gently; spores (Fig. 4. e) free. in mass pale reddish brown or coppery, pale brown by transmitted light, $6-8 \mu$ in diam., faintly reticulate, with about 7 meshes to half a great circle, and a faintly warted or smooth area of dehiscence. Plasmodium white, changing through rose to pale brown and dark brown before ripening. 
The distribution of $R$. jurana is not well known, but it is certainly not confined to higher altitudes, as Meylan thought. G. Lister already stated "similar aethalia are not unfrequent in the British Isles". In the collection of the British Museum I saw a specimen collected in Ireland (2822 BM). In the neighbourhood of Doorwerth it is quite common (N. E. NANNENGA-BREMEKAMP 164 (U), 254, 393, 977, 984, $1128,1208,1209,1254,1262,1275,1300,1303,1336,1343,1405$, $1528,1600(\mathrm{U}), 1863$ (U), $1903(\mathrm{U}), 1920,1930,1940,2037,2062$, $2070,2532,2563,2564,2565,2567,2568,2570,2581,2588,2589$, $2591,2592,2594,2596,2597,2603,2620,2624,2627,2630,2641$, $2645,2657,2682,2686,2691,2694,2695,2697,2702,2736,2780$, $2782,2783,2784,2785,2786,2787,2798,2834,2836)$. It occurs here simultaneously with $R$. lycoperdon, and not much in advance of the latter, as Meylan reports from the Jura. That the two species may be collected at the same time, proves that the difference in thickness of the cortex can not be due to weather conditions, as G. Lister suggested. At lower altitudes the aethalia may attain a larger size than Meylan gives, viz. up to $2.5 \mathrm{~cm}$ in diam., instead of $1 \mathrm{~cm}$ at the most. That more than one aethalium may be present, was not mentioned by Meylan either. I have found up to four growing together. $R$. lycoperdon forms, as a rule, but a single aethalium. The plasmodia as well as the ripe aethalia are in both species much relished by small beetles, that are apt to push beneath the aethalium, separating it from the substrate. This accounts for the fact that an aethalium that has just been formed, may totally disappear in one night. Gareful search in the vicinity will usually reveal parts of it.

$R$. jurana differs from $R$. lycoperdon, apart from the thinner cortex, by the anastomosing threads of the pseudo-capillitium, and as Meylan already noted, by the smaller and paler spores which, moreover, are more delicately reticulate with wider meshes and provided with a faintly warted area of dehiscence.

As far as the pseudo-capillitium is concerned, $R$. jurana is more or less intermediate between $R$. lycoperdon on the one hand and $R$. splendens and $R$. lobata on the other. As Meylan pointed out, the pseudo-capillitium may occasionally be very similar to that figured by $\mathrm{G}$. Lister for $R$. lobata.

5. Reticularia lobata Lister, Mon. Mycet.: 160. 1894; $\boldsymbol{R}$. rozeana Rost. apud Lister in Journ. of Bot. 29: 263. 1891, quoad specimen descriptum, haud quoad typum; Liceopsis lobata (Lister) Torrend in Bull. Soc. Port. Sc. Nat. 2: 63. 1908 (cf. Fig. 5-I).

Aethalia (Fig. 4-I-a) small and easily mistaken for sporangia, $0.4-1.1 \mathrm{~mm}$ in diam., usually closely clustered and angular by mutual compression, rarely solitary and then subglobose, according to Martin sometimes provided with a short flattened stalk, rusty brown or clay-coloured; cortex membranous, smooth, shining and iridescent; pseudo-capillitium (Fig. 5-I-b) usually scanty and then consisting of brown membranes and threads, sometimes absent; spores (Fig. 5-I-c) free, globose, 7-8 $\mu$ in diam., the thick part of the wall coarsely 

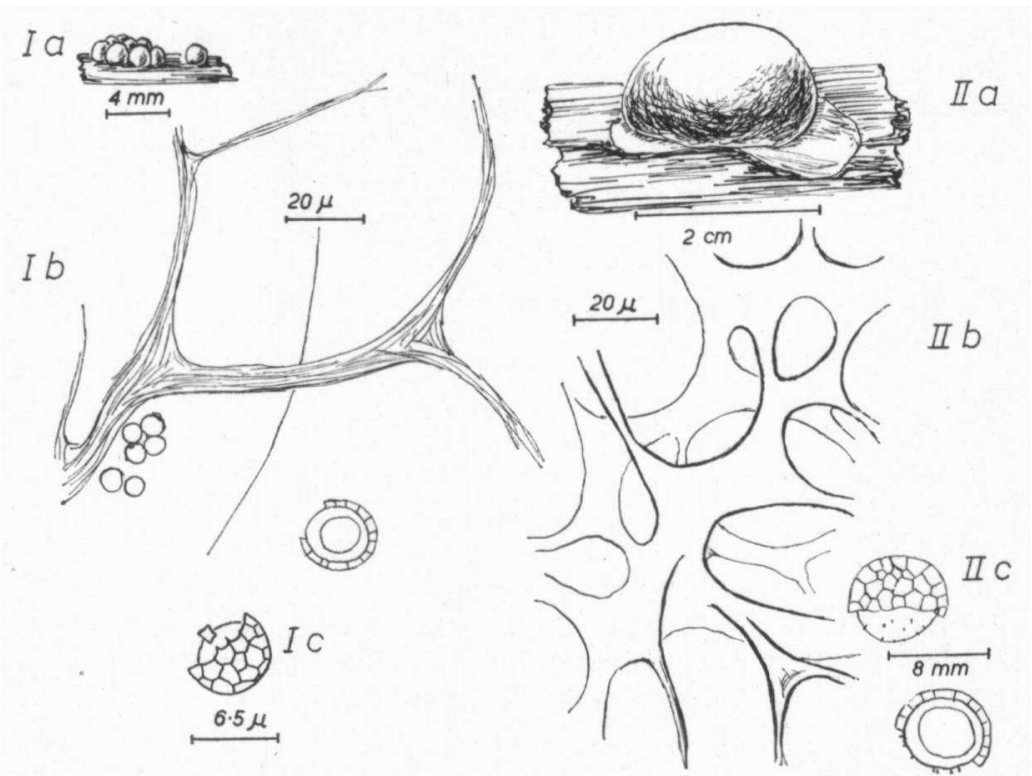

Fig. 5. I. Reticularia lobata Lister. a. group of aethalia; b. pseudo-capillitium; c. spores, one in optical section. II. Reticularia splendens Morg. a. aethalium;

b. pseudo-capillitium; c. spores, one in optical section.

reticulate, with about 6 meshes to a half great circle; the area of dehiscence smooth or with a fragmentary reticulation. Plasmodium, according to Lister, watery white.

This species occurs in Europe and North America. In the collection of the British Museum I could study the numbers 1448, 1449 and 3197 from England, and a specimen from Portugal collected by Torrend.

In Lister's original description the fructifications were regarded as aethalia, and Martin, who returned this species from Liceopsis to Reticularia, is of the same opinion. As the pseudo-capillitium is very similar to that of $R$. jurana, this must be accepted as the correct interpretation.

G. Lister says that the sporangia, as the aethalia are called by her, are sometimes confluent into a flat or globose "aethalium". However, when I studied the Lister Collection in May of this year, I did not find a single specimen in it which showed this feature, which according to her would not be rare, and for this reason it seems to me that the specimens which she had in mind, may have been misidentified, and that they belonged in reality to $R$. jurana. This would explain the wide range in spore size reported by her, viz. 6-10 $\mu$ in diam., whereas in the specimens examined by me they varied between 7 and $8 \mu$. For this reason $I$ have not included the feature mentioned by $G$. Lister in my description. If the specimens on which she based her opinion, had been available, the question could easily have been settled, as $R$. jurana and $R$. lobata differ not only in the size of the spores, but also in the relief of the latter, the area of dehiscence being 
in $R$. jurana usually finely warted instead of smooth or provided with a fragmentary reticulation, and in the far more abundant pseudocapillitium of this species.

I would like to thank here the Keeper of Botany, of the British Museum of Natural History, for the permission to study the Lister collection, and the Staff of the Cryptogamic Department for their kind assistance. A word of thanks is also due to Prof. Dr. G. W. Martin, who obliged me with specimens of Reticularia splendens, and Reticularia lycoperdon and its var. americana.

\section{SUMMARY}

On account of the reticulate spores with their large area of dehiscence and because of the structure of the pseudo-capillitium the monotypic genus Liceopsis and Enteridium splendens (syn. E. rozeanum) are returned to Reticularia.

It is argued that $R$.? rozeana can not with certainty be identified, but that it can not be regarded as conspecific either with $R$. Lobata or with $R$. splendens.

Of $R$. lycoperdon a var. americana is separated, differing from the type by its free spores.

A new species, $R$. intermedia, is described. It resembles $R$. lycoperdon in the dendroid pseudo-capillitium, but differs from the latter in the fragile cortex and in the filamentous structure of the pseudo-capillitium. It is known so far only from the vicinity of Doorwerth, province of Gelderland, the Netherlands. 